Portland State University

PDXScholar

$1-1-2013$

\title{
Accountability vs. Improvement: Seeking Balance in the Value of Academic Libraries Initiative
}

Meredith G. Farkas

Portland State University, meredith.farkas@pcc.edu

Follow this and additional works at: https://pdxscholar.library.pdx.edu/ulib_fac

Part of the Library and Information Science Commons

Let us know how access to this document benefits you.

\section{Citation Details}

Farkas, M. (2013). Accountability vs. Improvement: Seeking Balance in the Value of Academic Libraries Initiative. OLA Quarterly, 19(1), 4-7.

This Article is brought to you for free and open access. It has been accepted for inclusion in Library Faculty Publications and Presentations by an authorized administrator of PDXScholar. Please contact us if we can make this document more accessible: pdxscholar@pdx.edu. 


\section{Accountability vs. Improvement: Seeking Balance in the Value of Academic Libraries Initiative}

\author{
by Meredith Farkas \\ Head of Instructional Services, \\ Portland State University \\ mfarkas@pdx.edu
}

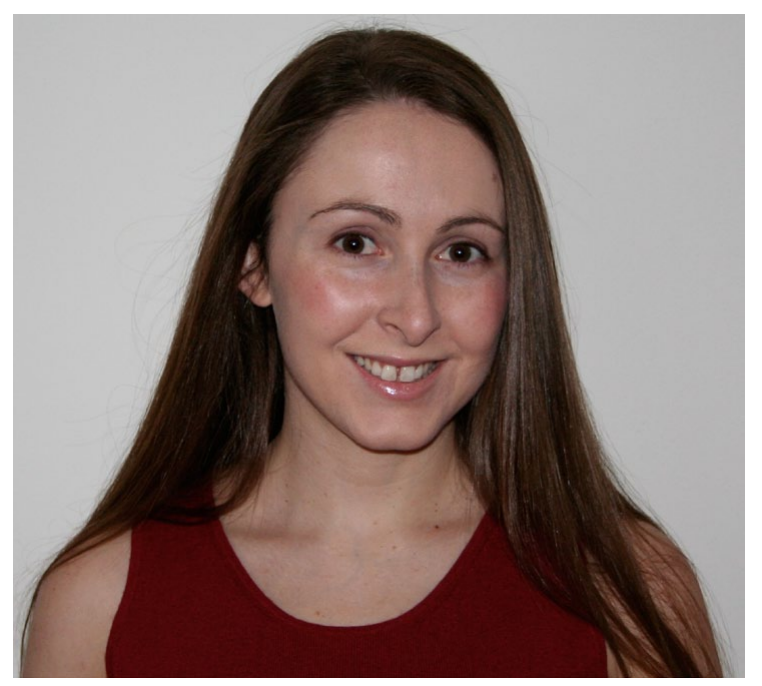

It should come as no surprise to librarians of any type that academic libraries are facing shrinking budgets and rising collections costs. With the growth of the accountability movement in higher education, academic libraries can no longer take for granted their position as "the heart of the campus." In 2009, in response to these trends, ACRL commissioned a study and developed a program focused on finding ways for libraries to demonstrate value and creating a research agenda around the subject of value. This initiative produced The Value of Academic Libraries: A Com-

prehensive Research Review and Report (Oakleaf, 2010) as well as a Summit for twenty-two library administrators, their institutional research heads, and their Chief Academic Officers to discuss value-focused topics.

When I first heard about The Value of Academic Libraries report, I was excited. It seemed like this initiative could galvanize libraries to move beyond simply reporting outputs books checked out, classes taught, etc. - and focus on the value of what we do and provide. While I can't say I ever minded the Director at my previous institution praising me for increasing the number of classes we taught, I always felt that the quantity of classes taught was meaningless if we did not know whether students were developing the skills they needed to be successful. If the Value of Academic Libraries movement was focused on outcomes and assessment, I was on-board.

When I read the full study, including the research agenda, I realized I'd had it wrong. The research agenda was largely focused on demonstrating correlations between library collections, instruction, or use and student or faculty success. This was not information designed to help libraries improve; it was focused on libraries showing a relationship between the library and indicators that are meaningful to campus administrators. When a library can show a significant correlation between library usage and student achievement, or even if they can't, what can they do with that data to improve student success?

Since the report was published, a number of institutions have published studies focused on demonstrating a significant relationship between library use and student achievement, student retention, and more (Cox \& Jantti, 2012; Haddow \& Joseph, 2010; Stone, Ramsden, \& Pattern, 2011; Wong \& Webb, 2011). However, these studies seem focused on providing evidence of the library's value to outside entities, not on actually improving library services. One slightly more promising study recently came out of the University of Minnesota. Their library was engaged in a major initiative to collect data on how students used library resources - collections, instruction, electronic reference, etc. - and to correlate that usage information to demographic data including status, major, and GPA (Nackerud, Fransen, Peterson, \& Mastel, 2013). While primarily focused on the correlation between library use and GPA, the study at least gives the library a better idea which majors use the library a great deal and which hardly use it at all. 
The values research coming out of these institutions is very interesting, but more focused on accountability than assessment. I'm curious to hear what the University of Minnesota does with this data next, if anything, since the authors freely admit in their upcoming article that, to date, the data has not been used for anything more than demonstrating library value to administrators (Nackerud et al., 2013). Will they use it to realign their collection development priorities or to make the case for instruction in areas that are not using library resources? Libraries have always collected a lot of data; they haven't always been good at using it.

When I began to hear librarians conflating library assessment and library value research as if they were the same thing, I became concerned that perhaps a focus on demonstrating value might discourage librarians from putting their energies into assessment focused on service improvement. It can be difficult to get instruction librarians - or any educators for that matter - to buy into the value of doing assessment. Like those who have conflated assessment and values research, many associate assessment with accountability. In surveying the literature (Haviland, 2009; Hiller, Kyrillidou, \& Self, 2008; Lakos \& Phipps, 2004; Marrs, 2009), it is clear that many in higher education see assessment as something demanded from above that is not designed at all for their benefit. They fear getting negative results and how those results might be used against them. Many instruction librarians are already pressed for time and feel they know when and whether their students are learning without doing assessment. I will admit that I felt that way as a new librarian until I came to understand that doing assessment was not just about showing the accreditation team that we were doing assessment. Assessments, when well designed, could lead to learning that improves my own teaching and work. Unfortunately, this kind of epiphany tends to come only from actually doing meaningful assessment and learning from the results.

Getting instruction librarians to internalize the value of assessment is hard enough without the focus of assessment shifting from learning to demonstrating value. With that shift, all of those fears about assessment return, because when the focus is on demonstrating value, poor assessment results become a liability. And when librarians fear negative assessment results, they will tend to design "safe" assessments that will provide positive results, but will not likely provide useful results.

Meaningful assessment of student learning is not as neat and clean as values research. Students do not live in controlled settings where they receive a single intervention whose impact can then be measured. Even instructors who work with students for an entire academic term don't know if they are the sole cause of a student's success or failure. Doing pre-tests and post-tests within a single library instruction session is virtually the only way to know, beyond a shadow of a doubt, what impact library instruction has had on a group of students. However, it is through the authentic assessment of student work - the research papers and other works produced in their class - that we can really measure whether students are able to apply what they have learned.

This summer, my colleagues and I are going to be assessing Freshman Inquiry student portfolios using an information literacy rubric we're developing. We will not be able to tell from our assessment what role library instruction played in their success (or lack thereof), but we will have a better sense of where students are having problems and where we need to focus our efforts in the future. Combined with developing a better understanding through surveys - of how to better support the instructors and peer mentors in Freshman 
Inquiry, we will hopefully be on the road to demonstrating our value to faculty and students through targeted and well-informed support.

I fear that this shift toward value research will not provide us with data or information that informs practice. I also find it difficult to believe that a library can make a compelling value proposition with correlational data. For example, Oakleaf (2010) states that it might be "helpful to know that students who have participated in three or more library instructional episodes over the course of their college career have a significantly higher GPA" (p. 96). Even if this could be demonstrated, it by no means indicates that library instruction was responsible for that success. There are any number of factors at play that could contribute - their major, their choice of courses, their instructors, etc. Perhaps faculty who request library instruction are more likely to scaffold their research assignments, leading to better student outcomes. I recognize that some administrators might actually be convinced of the library's value through correlational evidence, but if the research does not lead to assessment to better understand the why behind the numbers, then the library will not know how to improve.

The Value of Academic Libraries initiative has brought many good ideas to libraries. It has called into question our current reliance on input and output measures while helping libraries focus on those things University administrators consider significant. Values research has made libraries more aware of the usefulness of partnerships with offices of institutional research. Finally, I think the initiative has helped to demonstrate the fact that libraries need staff in-house who have the skills necessary to design quality assessments, analyze the data, and make that data tell a story that is meaningful to administrators.

I am currently conducting a survey with colleagues from the University of Illinois, Urbana-Champaign and the University of North Carolina, Greensboro that explores what elements facilitate and hinder libraries in developing a culture of instructional assessment. What I see coming up time and again in the preliminary results is that many libraries do not feel they have the time or expertise to do assessment well. While I would like to believe that assessment and values research can co-exist in academic libraries, I wonder if this will hold true at small and/or understaffed libraries. I fear that, when push comes to shove, libraries with limited resources will choose to focus on values research over assessment. In the current environment, who can blame them?

I recognize the importance of libraries demonstrating value to those who determine our funding levels, but I think a better balance needs to be struck between assessment focused on improvement and research focused on accountability. The Value of Academic Libraries initiative seems focused on getting libraries to answer the question "how can we prove that the library is valuable" when the question I feel we should be asking is "how do we know the library is valuable?" There is a considerable difference between coming from a place where we assume we are valuable and try to find evidence that confirms it and coming from a place where we assume nothing and try to determine whether or not we are providing value. As service-oriented organizations, we should also be learning organizations, focused on learning not only what we are doing right, but also what we could be doing better. Perhaps with such an orientation, we can conduct research that both demonstrates value and helps us to improve. 


\section{Works Cited}

Cox, B., \& Jantti, M. (2012). Discovering the Impact of Library Use and Student Performance. Educause Review Online. Retrieved from

http://www.educause.edu/ero/article/discovering-impact-library-use-and-student-performance

Haddow, G., \& Joseph, J. (2010). Loans, Logins, and Lasting the Course: Academic Library Use and Student Retention. Australian Academic \& Research Libraries, 41(4), 233-244.

Retrieved from http://www.alia.org.au/publishing/aarl/41/AARL_2010_41_4.pdf

Haviland, D. (2009). Why are faculty wary of assessment? Academic Leadership Journal, 7(3).

Hiller, S., Kyrillidou, M., \& Self, J. (2008). When the evidence is not enough: Organizational factors that influence effective and successful library assessment. Performance Measurement and Metrics, 9(3), 223-230. Retrieved from http://hdl.handle.net/1773/19932

Lakos, A., \& Phipps, S. E. (2004). Creating a Culture of Assessment: A Catalyst for Organizational Change. Portal: Libraries and the Academy, 4(3), 345-361. Retrieved from http://www.escholarship.org/uc/item/0843106w

Marrs, H. (2009). Perceptions of College Faculty Regarding Outcomes Assessment. International Electronic Journal for Leadership in Learning, 13(2). Retrieved from http://www.eric.ed.gov/PDFS/EJ940619.pdf

Nackerud, S., Fransen, J., Peterson, K., \& Mastel, K. (2013). Analyzing Demographics: Assessing Library Use Across the Institution. Portal: Libraries and the Academy, 13(2).

Preprint retrieved from http://conservancy.umn.edu/handle/143309

Oakleaf, M. (2010). Value of Academic Libraries: A Comprehensive Research Review and Report. Chicago: Association of College and Research Libraries. Retrieved from http://www.acrl.ala.org/value/?page_id=21

Stone, G., Ramsden, B., \& Pattern, D. (2011). Looking for the link between library usage and student attainment. Ariadne, (67), 1-7. Retrieved from http://www.ariadne.ac.uk/issue67/stone-et-al/

Wong, S. H. R., \& Webb, T. D. (2011). Uncovering Meaningful Correlation between Student Academic Performance and Library Material Usage. College Research Libraries, 72(4), 361-370. Retrieved from http://crl.acrl.org/content/72/4/361.abstract 